\title{
LIVING ARRANGEMENTS AND SUPPLEMENTAL SECURITY INCOME RECEIPT AMONG THE AGED
}

\author{
Melissa M. Favreault* \\ Douglas A. Wolf \\ CRR WP 2004-03 \\ Released: February 2004 \\ Draft Submitted: December 2003 \\ Center for Retirement Research at Boston College \\ 550 Fulton Hall \\ 140 Commonwealth Ave. \\ Chestnut Hill, MA 02467 \\ Tel: 617-552-1762 Fax: 617-552-1750 \\ http://www.bc.edu/crr
}

* Melissa Favreault is a senior research associate at the Urban Institute. Douglas Wolf is the Gerald B. Cramer Professor of Aging Studies in the Maxwell School of Citizenship and Public Affairs at Syracuse University. The research reported herein was performed pursuant to a grant from the U.S. Social Security Administration (SSA) to the Center for Retirement Research at Boston College (CRR). The opinions and conclusions are solely those of the authors and should not be construed as representing the opinions or policy of SSA or any agency of the Federal Government or of the CRR. The authors gratefully acknowledge research assistance from Jillian Berk and Elaine Maag. We also thank Paul Davies, Mark Hayward, Howard Iams, Richard W. Johnson, William Marton, Kathleen McGarry, Kalman Rupp, and Karen Smith for helpful comments on earlier versions of this and related work.

(C) 2004, by Melissa M. Favreault and Douglas Wolf. All rights reserved. Short sections of text, not to exceed two paragraphs, may be quoted without explicit permission provided that full credit, including (C) notice, is given to the source. 


\section{About the Center for Retirement Research}

The Center for Retirement Research at Boston College, part of a consortium that includes parallel centers at the University of Michigan and the National Bureau of Economic Research, was established in 1998 through a grant from the Social Security Administration. The goals of the Center are to promote research on retirement issues, to transmit new findings to the policy community and the public, to help train new scholars, and to broaden access to valuable data sources. Through these initiatives, the Center hopes to forge a strong link between the academic and policy communities around an issue of critical importance to the nation's future.

\section{Center for Retirement Research at Boston College}

550 Fulton Hall

140 Commonwealth Ave.

Chestnut Hill, MA 02467

phone: 617-552-1762 fax: 617-552-1750

e-mail: crr@bc.edu

http://www.bc.edu/crr

Affiliated Institutions:

American Enterprise Institute

The Brookings Institution

Massachusetts Institute of Technology

Syracuse University

Urban Institute 


\title{
Living Arrangements and Supplemental Security Income Receipt among the Aged
}

\begin{abstract}
Declines in health and financial resources lead many older Americans to turn to coresidence and the Supplemental Security Income (SSI) program for support. A growing literature examines coresidence choices and SSI participation, stressing the importance of each for vulnerable aged persons. Little research, however, considers how these processes intersect. Because SSI provides Medicaid access but reduces benefits if one shares a residence, the program alters both the necessity of and the incentives for coresidence. We explore interactions between SSI participation and living arrangements by developing two joint models of the two decisions for members of the SSI-eligible population. In these models, we express the probability of SSI receipt and living with kin and joint SSIliving arrangement states as functions of individual and family attributes. We estimate model parameters using data from the 1990 to 1993 panels of the Survey of Income and Program Participation (SIPP) matched to administrative records on earnings and program participation. Our results provide tentative support for the hypothesis that these two processes should be considered jointly.
\end{abstract}




\section{Introduction}

For the most vulnerable of the aged, coresidence and the Supplemental Security Income (SSI) program are vital sources of support. Older Americans experiencing declines in health and financial resources often move in with their children or other relatives to cut down on their expenses and/or to give or receive personal assistance. This private mechanism for transferring resources has an enormous impact on aged well-being, with some estimates suggesting that coresidence may reduce overall incidence of elderly poverty by as much as 42 percent (Rendall and Speare 1995). SSI, in contrast, provides public transfers to vulnerable elderly and disabled persons. Known as the "program of last resort," it grants means-tested benefits to those individuals who do not receive Social Security or private pension benefits or whose benefits are very low. While federal SSI benefits cannot bring an individual's or couple's income over the poverty line (Committee on Ways and Means 2003), their impacts are clearly significant. Many individuals and couples who receive benefits from SSI receive almost all of their income from the program (Social Security Administration 2002a: Table 7.D1, Social Security Administration 2002b: Table 36).

Recognizing their importance to the aged most at risk of poverty, scholars have described and explained both coresidence choices and SSI participation in a growing literature. Little research, however, has examined the intersection of these two decisions. This paper seeks to fill this important gap. Because the SSI program both reduces the benefits of those who share a residence and provides recipients with access to Medicaid, the program effectively alters both the necessity of and the incentives for coresidence. Understanding interactions between SSI and living arrangements may thus be necessary for estimating the true fiscal and distributional impacts of changes to Social Security and SSI, especially in cases of fundamental structural reform. ${ }^{2}$

We explore interactions between SSI participation and living arrangements by developing two joint models of the two decisions for members of the SSI-eligible population. The models predict SSI receipt, living arrangements, and joint SSI-living arrangement states as functions of individual and family attributes. We estimate model parameters using data from the 1990 to 1993 panels of the Survey of

\footnotetext{
${ }^{2}$ The Social Security Administration's recent report on SSI's income and resource exclusions (Social Security Administration 2000) underline the need for detailed analysis of the needs of individuals and families with income and assets near SSI eligibility thresholds.
} 
Income and Program Participation (SIPP) matched to administrative records on earnings and program participation. We find that individuals respond to SSI incentives, increasing participation when benefits are higher and making coresidence choices that maintain their benefits. We find modest evidence that living arrangements and SSI receipt choices are connected for low-income individuals and couples. SSI participation appears to depress levels of coresidence, and coresidence appears to mute SSI participation.

\section{Background on SSI}

SSI provides cash payments (generally supplemented by Food Stamps and Medicaid) to lowincome aged (defined as those over age 65), blind, and disabled people who meet stringent needs standards. ${ }^{3}$ Congress passed the legislation creating the SSI program in 1972, and the program first disbursed benefits in 1974. SSI emerged as a compromise in the wake of the heated debate over Richard Nixon's proposed Family Assistance Plan (FAP). ${ }^{4}$ While FAP's designers sought to institute an income floor for all Americans, Congress in essence created such a floor for a select segment of the population, groups generally perceived as unquestionably "deserving" of assistance, through the SSI program. Poverty rates for the aged were quite high at the SSI program's start (14.6 percent in 1974, a statistic that increases considerably if we include those aged persons "near" poverty). ${ }^{5}$ They have since declined markedly (as evidenced by a rate of 10.4 percent of elders in poverty in 2002). ${ }^{6}$ The SSI program thus from its inception seemed to be well-targeted to a high-risk population, and perceptions have changed little over the years.

\footnotetext{
${ }^{3}$ These standards include both an income test and an asset test. We describe the income test in detail below. For 2003 , the asset test standard is "countable resources" not exceeding $\$ 2,000$ for an individual or $\$ 3,000$ for a couple. In determining countable resources, the value of a home and of personal effects (within reasonable limits set by the Social Security Administration) are excluded, as are the value of an auto (up to $\$ 4,500$ or, if used for medical purposes, one hundred percent of the vehicle's value), the value of life insurance cash surrender (up to $\$ 1,500$ ), and burial funds (also up to $\$ 1,500$ ).

${ }^{4}$ Burke and Burke (1974), for example, provide details on the FAP debate.

${ }^{5}$ Aged poverty rates were much higher just before SSI's start: for example a rate of 29.5 percent of the aged population in official poverty observed as late as 1967.

${ }^{6}$ This aged poverty level is higher than aged poverty rates in many other societies of comparable economic development, but compares quite favorably to the U.S. children's poverty rate of 16.7 percent for the same year.
} 
Historically, the income floor that SSI provides to the aged has been set at a mark less than the poverty level. In 2003, the monthly federal SSI benefit for an individual with no other countable income living independently is $\$ 552$; for a similar couple, the benefit is $\$ 829$. This is about 74 percent of the poverty level for individuals and about 82 percent of the poverty level for couples. ${ }^{7}$ The SSI program's benefits interact with other parts of the social welfare system and with the social insurance system. Significant fractions of SSI beneficiaries, almost 60 percent of those over age 64, receive Social Security benefits that put them closer to the poverty threshold (Social Security Administration 2002a: 289). Food Stamps further enhance the economic security of many SSI recipients.

The federal government covers the costs of the SSI program through general revenues. States have the option to supplement the federal benefit, and most states provide some form of supplement. ${ }^{8,9}$ This feature of SSI is quite interesting, as these state supplementation levels vary widely. In January 2000, the difference between the highest and lowest state monthly combined SSI and Food Stamp payments for aged individuals living independently (excluding Alaska and Hawaii) without countable income was $\$ 165$; for aged couples living independently, this difference was $\$ 322 .{ }^{10}$ While these are modest in absolute terms, they are considerable in percentage terms. Although most states with higher payment levels (for example, Alaska) have relatively high costs of living, the two factors are not perfectly correlated. State-to-state variation in benefits thus implies different incentive structures for people participating (or deciding to participate) in the program in different parts of the country. These differences are changing fairly rapidly, as the real value of most state supplements has eroded considerably over the past decade (Committee on Ways and Means 2003: Table 3-5 and 3-6). (Supplements were thus higher at the time of our sample.)

The federal SSI benefit is reduced by up to one-third when one resides in another person's home. Under the language of the law, a person is considered to be living in another's home if he or she

\footnotetext{
${ }^{7}$ This estimate uses the 2003 HHS poverty guideline as the denominator (and not an aged poverty threshold).

${ }^{8}$ The federal government requires that states maintain income levels of those who had been participants of one of the state-level programs subsumed by the SSI program. Only a small percentage of those currently receiving SSI, less than 0.1 percent, are affected by this provision.

${ }^{9}$ Arkansas, Georgia, Kansas, Mississippi, Tennessee, and West Virginia are the states that did not provide supplements. The Commonwealth of the Northern Mariana Islands also does not supplement SSI.

${ }^{10}$ Sources for these figures are Tables 3-7 and 3-8 in Committee on Ways and Means (2003). These differences are hard to capture faithfully, given that some states, like California, have substituted cash for Food Stamps, and most
} 
"receives support and maintenance in kind from such a person." Specifically, for a person to be subject to the benefit reduction, he or she must not own the home or contribute to the rent or mortgage, must not buy food separately, must not eat out rather than eating with members of the household, and must not pay a pro rata share of food and shelter expenses (Committee on Ways and Means 2003). ${ }^{11}$ The Social Security Administration reports that only about 5.2 percent of SSI recipients aged 65 and older are subject to reduced benefits for residence in another person's household, while an additional 2.8 percent are in institutional care covered by Medicaid (Social Security Administration 2002a: 293). ${ }^{12}$ This is significantly lower than the fraction of SSI recipients who share accommodation, suggesting that SSA program administrators interpret this part of SSI law fairly liberally (Davies et al. 2002).

Nonetheless, these regulations have been the source of some criticism (Social Security Administration 2000).

SSI recipients may earn up to 65 dollars per month and receive up to 20 dollars per month from any source (including, for example, Social Security benefits) without having their SSI benefits reduced. Beyond these exclusions, the SSI program treats earned and unearned income differently. Earned income is taxed at 50 percent (i.e., one's SSI benefit is reduced by 50 cents for every dollar one earns), while unearned income is taxed at one hundred percent (i.e., one's SSI benefit is reduced by one dollar for every extra dollar in Social Security, pension, or asset income that one receives).

\section{Review of Literature on SSI and Living Arrangements}

In comparison to public assistance programs like Aid to Families with Dependent Children (AFDC) and its successor Temporary Assistance for Needy Families (TANF), SSI has received relatively little media or scholarly attention. This has led some to label it the "forgotten safety net" (Select Committee on Aging 1987). Since the program's 1974 inception, a main focus of research has been the relatively low level of take-up of SSI benefits among the aged. SSI research has consistently revealed participation rates that are around 50 to 60 percent of the eligible aged population (see, for

\footnotetext{
economists argue that an equivalent cash benefit is worth more to recipients than Food Stamps with the same face value.

${ }^{11}$ For additional details on these regulations, see Social Security Administration (2000).

${ }^{12}$ Far more cases require documentation of living arrangements, according to Social Security Administration (2000).
} 
example, McGarry 1996, Warlick 1982, Urban Systems 1981). One more recent study (Davies et al. 2002) suggests participation of about 63 percent.

Proposed explanations for such low SSI take-up have included lack of information about the program, physical isolation or other barriers to making an application (e.g., no access to transportation), and a possible stigma attached to receiving means-tested, as opposed to social insurance, benefits. Analyses of take-up have often revealed that individuals who can expect higher benefits from SSI are more likely to participate than individuals who can expect smaller benefits. Net of benefit levels, those individuals who have lower incomes have been found to participate in SSI at higher rates. McGarry (1996) finds that higher income variance is associated with lower probability of participation. Many analysts find that participation in other social programs (e.g., Social Security) leads to higher participation in SSI. Foreign-born persons, not surprisingly, are less likely to be entitled to Social Security than are native born persons, and hence receive SSI benefits at higher rates and have higher average benefit levels when receiving SSI (Scott and Ponce 1994). Because of welfare reform, citizenship status is now an important predictor of SSI participation as well (Parrott, Kennedy, and Scott 1998).

A substantial literature discusses patterns in the living arrangements of aged Americans and proposes explanations for changes in these patterns over time (see, for example, Börsch-Supan 1990, Kotlikoff and Morris 1990, Macunovich et al. 1995, Wolf and Soldo 1988). ${ }^{13}$ Factors that are hypothesized to influence an individual's decisions about living arrangements in old age include her/his economic resources, her/his health, the economic and social costs/benefits associated with different living arrangements, social norms, and the types of alternatives that are available to her/him. The amount and character of alternative living arrangements that each person faces depends crucially on his or her kin network (Wolf 1994, provides a summary of the literature on kin availability and living arrangements). Individuals with more surviving kin (e.g., spouses, parents, children, siblings, nieces/nephews) clearly have more opportunities both for support in independent living and also for coresidence than do individuals with fewer or no surviving kin. Some of the recent literature in this area focuses on coresidence as a two-sided matching problem. This line of research suggests that in examining the living arrangements of the aged, one needs to examine not only the quantity of kin, but 
also the composition of the kin network and the characteristics of individual kin. For example, researchers have found that unmarried children are more likely to share living arrangements than married children.

Little in the literature has addressed the overlap between coresidence and SSI, with the exception of a few descriptive pieces (for example Kochhar and Scott 1997, Social Security Administration 2000). This descriptive work has revealed that the plurality of SSI recipients over age 64 reside alone (about 45 percent), an additional 16 percent reside with just a spouse and children, and over a third have some other type of living arrangement (Kochhar and Scott 1997). It has also revealed that members of the SSI population change living arrangements fairly frequently, with nearly a quarter of SSI recipients ages 65 and older (24.1 percent) changing their residence at least once in a three year period (Ibid). Estimates in the Social Security Administration's report on SSI simplification (2000) suggest that those persons who receive reduced SSI benefits because of support and maintenance in kind are less likely than other SSI beneficiaries to reside in homes that have poverty level incomes.

Coresidence has been addressed as just one minor aspect of SSI in the literature on the program. McGarry's research (2000: 30), for example, reveals that elderly individuals who share a residence are far more likely to be eligible for SSI than those elders who live alone. She also finds that the distribution of individuals in different living arrangements is nearly the same for SSI participants as it is for nonparticipants.

Another unique study in this area is that of Tissue and McCoy (1981), who analyzed transitions in living arrangements among poor, elderly unmarried persons between late 1973 and late 1974. During this time interval the persons studied experienced income increases due to the introduction of the SSI program. These income increases, while small in absolute size, were large in relative terms, amounting to an 18.3 percent increase, on average, among those living alone at baseline, and a 24.6 percent increase on average among those living with others. This study uncovered some significant effects of these SSI-induced income changes on living arrangements, some of which were unexpected. Among those living alone at baseline, income increases produced statistically significant increases in coresidence over the year. The reason for this increase was that others moved in with the SSI recipients (the recipient's move to the household of someone else was a distinct outcome in this analysis). Also,

\footnotetext{
${ }^{13}$ We use the terms "coresidence" and "shared living arrangements" interchangeably.
} 
among SSI recipients living with others at baseline, the income increases significantly increased the chances of moving out of the shared household by 1974.

Another study that has addressed the relationship between SSI and living arrangements is McGarry and Schoeni (2000), who model successive decennial census living-arrangements data for the period 1940 to 1990 . The central focus of their analysis is the role of Social Security benefits on living arrangements, ${ }^{14}$ but separate effects of OAA/SSI (in main-effects and interaction-effects form) are identified in their model. They find that among women with low levels of education, the SSI maximum benefit amount is associated with significant reductions in the chances of living with children (implying a significant increase in the chances of living alone).

\section{Hypotheses about the Relationship Between Living Arrangements and SSI}

There are several possible ways to examine the relationships between living arrangements and SSI take-up. The first is to consider the influence of living arrangements on the decision to be on, to enter, or to leave SSI. Conversely, one can try to identify the influence of SSI on the decision to live with others or to change or maintain one's living arrangements. Lastly, one can consider the decisions together.

In considering the first relationship (the decision to be on or take up SSI), we assume that individuals weigh the costs of participating in SSI (for example, the time it takes to collect documentation to verify eligibility) and the benefits of receiving SSI (the cash benefits and, for many, access to Medicaid), and take up benefits when the gains exceed the costs. We expect that, in making their decisions to enter or leave SSI, people will respond to incentives. The fact that under some conditions SSI benefits are smaller if one lives in another's home should thus, all else equal, make the program less attractive to individuals who are sharing a residence. This assumes, of course, that participants are aware of the SSI reduction for living in another's home and believe that it will be enforced.

We expect individuals to make like considerations when choosing their living arrangements. If an SSI recipient is living independently and knows that her/his SSI benefit will be reduced if she/he

\footnotetext{
${ }^{14}$ Engelhardt, Gruber, and Perry (2002) focus on Social Security's effects on living arrangements using CPS data, and similarly find that benefit reductions lead to increased coresidence.
} 
moves in with relatives, we would expect that she or he would be less likely to change living arrangements than a similar person who does not receive SSI (again, assuming awareness of the regulation and expectation of its enforcement). Survey research has consistently shown that aged persons prefer to live independently. Access to Medicaid, including home care services that can accompany program participation, may make it easier to remain independent if one is receiving SSI benefits. Given, as noted above, that SSA interpretation of living in another's home appears to be quite liberal, this latter aspect of SSI might be more important than the cash benefits themselves.

Health or disability is expected to have a complex relationship with both living arrangements and SSI receipt. In most states SSI recipiency more or less automatically conveys Medicaid recipiency, but many states adopt "medically needy" provisions that permit SSI ineligibles to obtain Medicaid benefits. For the disabled elderly, Medicaid is an important payment source, both for nursing home costs and (to varying degrees) home care. Thus an SSI-eligible nonparticipant may apply for Medicaid in order to obtain Medicaid-financed home care, and through their contact with the public assistance bureaucracy become an SSI recipient as well. Moreover, the Medicaid-financed home care may permit the recipient to maintain independent living arrangements, at least for moderate levels of disability. At more severe levels of disability, Medicaid may be unable to provide enough home care to meet the person's needs, placing the recipient in the position of entering a nursing home, or coresiding with a caregiver but risking the loss of SSI. These interacting programmatic features, further interacting with disability and health "shocks," may contribute to complex SSI-living arrangement dynamics. However, due to inherent limitations of our data, especially the dynamics of health and disability, we are unable to identify such trajectories.

A final note on our hypotheses is that virtually all past research on coresidence among the aged population has used population samples (or, more precisely, samples of the noninstitutional population). Because our sample of SSI eligibles is very disadvantaged, we therefore need not necessarily expect to replicate findings from the past literature. Most SSI literature, on the other hand, focuses on the eligible population, so consistency with the literature is a more firmly grounded expectation. 


\section{Methods and models}

To test our hypotheses about the interrelationship between SSI participation and living arrangements, we produced a variety of descriptive tabulations and estimated a range of multivariate models. We model three separate dependent variables: 1.) binary SSI state (collecting or not collecting benefits given eligibility); 2.) binary living arrangements state (sharing a residence or living independently, where living only with a spouse and/or children younger than age 30 or non-relatives of any age is considered living "independently"); and 3.) the four-outcome cross-classification of joint living arrangements-SSI state. We discuss the details of how we operationalize these variables below, in our data section.

In constructing our models, we endeavored to capture several important aspects of these processes. First, we take into account that coresidence and SSI receipt occur in a life-course context. Each depends on lifetime accruals of wealth, including Social Security and pension entitlement, and social capital. Second, the processes may be closely connected, such that one influences the other or even that potential SSI participants make these choices jointly.

To jointly consider SSI and living arrangements, we use two alternative specifications. The first is a bivariate probit model. This specification allows us to consider the two processes as separate equations, while permitting their error terms to be correlated. We express each outcome (y1 and y2) as a function of an intercept $(\alpha)$, timevarying covariates $\left(\beta x_{i t}\right)$, and this error $\left(\varepsilon_{i t}.\right)$. The model thus takes the following form:

$$
\begin{gathered}
\operatorname{Prob}\left\{\mathrm{y} 1_{\text {it }}=1\right\}=\alpha_{1}+\beta_{1} \mathrm{X} 1_{\text {it }}+\varepsilon_{1 i t} \\
\operatorname{Prob}\left\{\mathrm{y} 2_{\text {it }}=1\right\}=\alpha_{2}+\beta_{2} \mathrm{X} 2_{\text {it }}+\varepsilon_{2 i t} \\
\text { Where } \operatorname{cov}\left[\varepsilon_{1 t i}, \varepsilon_{2 i t}\right]=\rho
\end{gathered}
$$

If the two error terms are indeed correlated $(\rho \neq 0)$, then we have evidence that we should consider the two processes jointly.

The second approach that we use for jointly considering SSI and living arrangements is a multinomial logit (MNL) model. The dependent variable in this model represents a cross-classification of our two binary variables, one distinguishing living alone versus with others, and the other distinguishing SSI receipt and nonreceipt. This yields four states: 1.) sharing a residence and collecting SSI; 2.) sharing a residence and not collecting SSI; 3.) living independently and collecting SSI; and 4.) living 
independently and not collecting SSI. If $Z_{1}(=0), Z_{2}, Z_{3}$ and $Z_{4}$ represent unobserved indices corresponding to outcomes $Y=1, \ldots, 4$, then our model takes the form:

$$
\begin{gathered}
\operatorname{pr}\left\{Y_{i t}=1\right\}=\frac{1}{1+e^{Z_{i 2 t}}+e^{Z_{i 3 t}}+e^{Z_{i 4 t}}} ; \\
\operatorname{pr}\left\{Y_{i t}=2\right\}=\frac{e^{Z_{i} 2 t}}{1+e^{Z_{i 2 t}}+e^{Z_{i 3 t}}+e^{Z_{i 4 t}}} ; \\
\operatorname{pr}\left\{Y_{i t}=3\right\}=\frac{e^{Z_{i 3 t}}}{1+e^{Z_{i 2 t}}+e^{Z_{i 3 t}}+e^{Z_{i 4 t}}} ; \text { and } \\
\operatorname{pr}\left\{Y_{i t}=4\right\}=\frac{e^{Z_{i} 4 t}}{1+e^{Z_{i 2 t}}+e^{Z_{i 3 t}}+e^{Z_{i 4 t}}}
\end{gathered}
$$

The index functions $Z_{2}, Z_{3}$ and $Z_{4}$ are linear-in-parameters combinations of unknown regression coefficients (again $\beta$ ) and exogenous variables $(\mathrm{X})$.

One might think of the distinction between these two models in the following way. In the case of the bivariate probit, one assumes that an individual chooses each of the binary outcomes, but that the unobserved factors that influence each choice are correlated. In the case of the multinomial logit, one assumes that individuals are choosing across four separate options, with each of the four options having distinct determinants.

In both of our models, the exogenous variables include standard demographic and economic variables, such as age, sex, race, nativity, marital status, education, work history (both total years in covered employment and years since one last worked), income sources (including Social Security, pensions, and asset income), as well as wealth (home and car ownership status). We also consider the variance of asset income. We additionally include an indicator for whether anyone in the household receives a Social Security benefit, under the assumption that the household's exposure to Social Security personnel increases the chance that the individual would be familiar with SSI. We include the value of the state supplement available given one's state of residence, filing status, and living arrangements, and further control for Southern residence, an important predictor in previous SSI 
analyses. ${ }^{15}$ While prior analyses have highlighted the role of the expected SSI benefit as a predictor of participation, we control for income by source instead of expected benefit. ${ }^{16}$ We also include the number of children ever born, the closest we can come to representing the composition of the kin group, which has been shown by past research to be an important correlate of living arrangements among the elderly. Given the role of health in both SSI and coresidence decisions, we include an indicator of whether one reports that one's health is fair or poor (as opposed to excellent, very good, or good). For married persons, model predictors include characteristics of the spouse, like his/her age. Finally, we integrate occurrence dependence by including an indicator of whether one has had, up to a year ago, any experience with SSI since the program's 1974 inception.

For both models, we present standard errors that correct for the multiple observations of individuals included in our sample (Stata Corporation 2001).

\section{Data}

Our analyses of the relationship between SSI and living arrangements rely on data from the 1990 through 1993 panels of the Survey of Income and Program Participation. We are able to link the SIPP records to administrative records on SSI history, earnings history (from 1951), and time of death. ${ }^{17}$ These data allow us to calculate SSI and Social Security eligibility and benefits more accurately than we could by relying on the survey data alone. Being able to verify SSI receipt is especially important, given that researchers have found that survey respondents frequently underreport social assistance income like SSI (Giannarelli and Wheaton 2000; see also the discussion in Davies et al 2002 and Huynh, Rupp, and Sears 2002).

SIPP's oversampling of low-income households is another advantage for our study. Together with our combining four SIPP panels, it means that we can examine a large number of SSI-eligible households. We further increase sample size by using person-waves as our unit of analysis. Using SIPP waves, which occur every four months, rather than single observations on individuals (or

\footnotetext{
${ }^{15}$ We define the South as consisting of Alabama, Arkansas, the District of Columbia, Florida, Georgia, Kentucky, Louisiana, Mississippi, Missouri, North Carolina, South Carolina, Tennessee, Texas, Virginia, and West Virginia.

${ }^{16}$ We divide income sources by the average wage to ensure comparability across years. For married persons, we express amounts for a couple, and adjust for economies of scale by dividing by the square root of two.

17 These files include the Summary Earnings Record (SER), Supplemental Security Record (SSR), and Numident.
} 
observations once per birth or calendar years) allows us to observe individuals' SSI status and living arrangements up to ten times. This allows for greater variation in key variables, like state supplements, which were changing annually over this period. In both of the models, we restrict our sample to personwave observations in which an individual is at least age 65, and thus categorically eligible for SSI aged benefits (given income and asset eligibility).

While these matched SIPP data are rich and uniquely suited to this task, they do have limitations. We draw the wealth measures that we use to determine SSI eligibility from a SIPP topical module. They thus reflect an individual's holdings at a point in time, and may not reflect assets as of another survey wave. The same is true of our health measure. Further, SSI has provisions for certain asset types about which SIPP does not ask questions (e.g., burial funds, life insurance cash surrender). The match rates for SIPP to administrative records are less than complete, about 88.7 percent for the longitudinal earnings records for members of our sample. The topcode for earnings record values is the taxable maximum for Social Security (\$87,900 per year in 2004). As we focus on the low-income, low-asset population, this topcoding is not a major concern.

\section{Defining key variables using SIPP}

\section{Living Arrangements}

For both our regressions and the descriptive analyses, we use a broad definition of coresidence that is based on whether one is sharing living quarters, regardless of who owns the dwelling or the amount he or she pays towards the rent, mortgage, or board. We thus consider an aged person to be coresiding either if a relative lives in the individual's house or if the individual lives in her/his relative's house. This form of coresidence is important for determining whether an individual or couple is in poverty. For example, if an adult child moves into a poor older parent's home to help the parent, the child's income could help to lift the aged person out of poverty.

To code this broad measure of coresidence, we combine the SIPP information on relationship to reference person variable with information on the ages of all persons with whom one shares a dwelling. (Census defines the reference person as the person in whose name the home is owned or 
rented, and in case of joint ownership by a couple, either may be listed as the reference person.) ${ }^{18} \mathrm{We}$ use an age cutoff in order to focus on relationships with some level of dependence in our models. If an aged person is sharing housing with at least one child or other relative who is over age 30 , we consider him or her to be coresiding. If he or she lives alone, with just a spouse, or coresides only with younger relatives (those under 30) or with non-relatives of any age (for example a roommate or partner), then we consider him or her to be living independently.

We opted for this more "social" definition of coresidence, rather than a fully programmatic one, for both conceptual and practical reasons. Conceptually, the SSA definition is quite narrow, and only encompasses a small fraction of shared living situations. Because the SSI benefit reduction for in-kind support and maintenance is just one facet of potential interactions between SSI and living arrangements (which also include, for example, Medicaid issues), a broader definition is warranted. On the practical side, the SIPP does not directly question respondents about all of the aspects of living arrangements that are specified in the law (for example, who pays what share of food expenses). Such information would be necessary to code an indicator that closely corresponded to SSA's in-kind support and maintenance definitions under the SSI program. Likewise, administrative records are insufficient for creating a programmatic living arrangements measure. ${ }^{19}$ We did conduct a sensitivity analysis in which we used an alternative definition that more closely corresponded to SSA intent in the SSI regulations, and compared these results to those in SSA records. ${ }^{20}$ These analyses suggested that the administrative classifications were correlated with both of the SIPP measures that we constructed, but that both of our measures classified far more people as sharing living arrangements than did SSA's measure, reflecting our broader intent. $^{21}$

\footnotetext{
${ }^{18}$ Because Census classifies all other people in the household in relation to the reference person, but does not necessarily define other people in the household in relation to one another, our measure treats reference persons and their spouses and others in the household asymmetrically. For the reference person and spouse, we consider relationships to all other persons in the household, while for people who are not the reference person or spouse, we only consider the relationship to the reference person.

${ }^{19}$ SSA administrative records include indicators of SSA's living arrangements classifications for SSI recipients, but do not include like information for non-recipients.

${ }^{20}$ Specifically, we used the information available on SIPP on the (unedited) relationship of each person in a household to the reference person. If a person is neither the reference person nor his/her spouse, but is related to the reference person, then we considered him or her to be living in another's home for SSI purposes.

${ }^{21}$ We also failed to classify some individuals SSA codes as living in another's home as coresiding, though this was a smaller problem in absolute terms.
} 


\section{SSI Eligibility and Participation}

We determine SSI eligibility by comparing individuals' and couples' self-reported income and assets to SSI thresholds in a procedure that mimics SSI regulations state by state. We first organize individuals into filing units based on whether they are categorically eligible for aged benefits (over age 65). ${ }^{22}$ Defining SSI eligibility poses challenges, given how difficult it is to measure assets and income accurately in a survey. When determining eligibility for SSI, we thus allow individuals' assets to exceed slightly (by 2.5 percent) the SSI thresholds. To evaluate income, we first check Social Security entitlement for those that administrative records reveal are qualified for benefits but have not yet taken them up. ${ }^{23}$ This is an important step in determining a person's eligibility, as SSI requires that prospective beneficiaries first apply for all other benefit sources for which they are eligible, including Social Security.

To determine whether one is an SSI participant, we rely primarily, but not solely, on SSA administrative records. These records include information on all federal benefits and federallyadministered state supplements, but not on state-administered state supplements to SSI. As our analyses include the state supplements, we combine self-reported data with administrative data. ${ }^{24} \mathrm{We}$ only supplement the administrative reports with a self-report if an individual lives in a state that administers its state supplement.

Comparing our own SSI eligibility indicator with administrative records, we find that we have assigned a significant number of "false negatives." Like Davies et al (2002), we find that our income and asset screens misclassify just about one quarter of the SSI recipients as ineligible for a benefit. Measurement error likely contributes to this problem, which could also be due in part to misinterpretations or violations of SSI regulations by beneficiaries and/or administrators. We include

\footnotetext{
${ }^{22}$ In a couple, it is possible that only one partner will be eligible.

${ }^{23}$ In computing these hypothetical Social Security benefits, we include entitlement to spouses' benefits, but cannot account for unobserved spouses (e.g., those spouses who died or who divorced their spouse before the survey).

${ }^{24}$ SIPP aggregates certain small states. Alaska, Idaho, Wyoming and Montana comprise one SIPP group, Iowa, North Dakota, and South Dakota comprise a second, and Maine and Vermont comprise a third. When assigning state supplement values to individuals from one of these states, we use a population-weighted average of the supplements from each state. This is problematic when states within groups have SSI supplements of significantly different sizes or offer supplements to different kinds of people.
} 
these misclassified cases in our descriptive analyses, for example the SSI participation estimates, but exclude them from the multivariate models.

\section{Results}

Descriptive Information on Living Arrangements

We begin by describing the living arrangements of individuals age 65 and over in the SIPP sample. Our SIPP estimates reveal that living arrangements among the aged are varied and complex (Table 1). Using the broader coresidence definition that we designed for the regression equations (the definition that classifies one as coresiding only if one lives with kin other than a spouse who are older than age 29), over 82 percent of seniors live independently, and just over 17 percent live in situations other than by themselves or with just a spouse, nonrelatives, and/or children under age $30{ }^{25}$ The most common coresidential arrangement is with one's child. Over one in eight adults ages 65 and older (12.4 percent) lives with at least one of her/his children. ${ }^{26}$ About 3.5 percent of our total sample lives with some other relative. These categories_-living with a child over age 30 and living with another relative (and the others listed under "with relatives other than or in addition to a spouse who are less than age 30") — are not mutually exclusive: a person can be living with both a child and a parent, or with both a child and a sibling. Indeed, in the SIPP we see many instances of multifamily households and of multigenerational families that include grandchildren. For example, about six percent of aged individuals whom we classify as living with a child who is age 30 or older are also living with "other relatives." The aged members of our sample are next most likely to live with a sibling (just under two percent). A very small fraction of people in the sample of 65-plus year-olds lives with their own parent (less than one percent). Given the ages of members of our sample, relatively few have surviving parents.

There are important distributional differences in who coresides. Columns 2 through 4 of Table 1 reveal marital status differences. ${ }^{27}$ Unmarried people are far more likely than married people to be

\footnotetext{
${ }^{25}$ Using this more restrictive definition in our sensitivity analyses, we classify only about a third as many people as sharing a residence: just over six percent of the sample.

${ }^{26}$ Many of these elders (about 8 percent) live with younger children as well.

${ }^{27}$ Our data (not shown) also indicate fairly clear age pattern to coresidence. The proportion of people who are coresiding declines through the mid 70's, presumably as children who had stayed in or returned to the parental home earlier in the parent's life gradually leave it. The proportion coresiding then begins to slowly increase again, as the parents or other older adults begin to move in with their children or other relatives, or as their children come back again to take care of them in their old age.
} 
sharing a residence, and unmarried women are more likely than unmarried men to share. The largest absolute difference between unmarried men and unmarried women is in the proportion living with children. While almost 17 percent of unmarried women live with children, just under 10 percent of unmarried men do.

\section{Descriptive Information on SSI Eligibility and Take up}

Our estimates of patterns of SSI eligibility and receipt in the SIPP are consistent with estimates from prior research (Table 2). Only about 11 percent of the SIPP population age 65 and older appeared eligible for an SSI benefit (column 1). Women are more than twice as likely as men to be eligible for program benefits (12.8 percent compared to 6.2 percent). Among both men and women, those in shared living arrangements (defined as described above) are more vulnerable than those living independently. About twice as many coresidents as persons living independently are eligible for SSI (for women, 21 percent of coresidents versus 11 percent of those living independently, and for men 12.3 percent of coresidents versus 5.4 percent of those living independently).

Also among both men and women, those who are not currently married are far more likely to be eligible for SSI than those who are married, with never married and divorced and separated persons even more likely to be eligible than widow(er)s, likely reflecting the availability of Social Security survivor benefits to many widows. For men, SSI eligibility rates are relatively stable across four broad age categories (65-69, 70-74, 75-79, and 80 plus), while for women, eligibility rates increase markedly with age. Not surprisingly, less-educated people are far more likely to be eligible for SSI than are more-educated people. There is clear patterning in SSI eligibility by race, ethnicity, and nativity as well. A far greater percentage of nonwhites than whites are eligible for benefits. Persons who were born

outside of the United States are more likely to be eligible than those born in the United States, who have greater opportunity to accrue entitlement to Social Security. Those with some form of wealth (defined here as ownership of either a house or a car) are less likely to be eligible for benefits than those without wealth. Those who report that their health is fair or poor are far more likely to be eligible for SSI than those who report more favorable health. 
Nearly three fifths (about 59 percent) of aged people who appear eligible for SSI actually take up benefits from the program (column 2). ${ }^{28}$ Overall, take-up is higher among women than among men (60 percent compared to 51 percent). Take-up rates for women in shared living arrangements are higher than for women living independently, while for men the reverse is true. Many of the patterns in take-up mirror the patterns in eligibility. For example, among both men and women, those with less income, those who are Hispanic, those who are foreign born, and those in fair or poor health are more likely to take up benefits, while those with more income and those who are homeowners are much less likely to participate in the program. Of course, to a large extent differences in take-up between some of these groups may reflect differences in their incomes. Certain patterns in these SSI participation rates may change when we control for income and available Social Security benefits.

\section{Descriptive Information on Overlap between Living Arrangements and SSI Take up}

Combining information on SSI with information on living arrangements, we find that the modal joint living arrangements-SSI states of SSI eligible older persons is collecting SSI benefits while living independently, accounting for about 42 percent of the SSI-eligible population (Table 3). Next most prevalent is living independently but not collecting SSI, at close to 29 percent. We also find that these joint living arrangements-SSI states vary by sex and marital status. Women in all marital status groups except the married are more likely to be in the share living arrangements/collect SSI state than are men in the same marital status groups. Men, in contrast, are most likely to occupy the neither share living arrangements nor collect SSI group in all marital status groups.

\section{Multivariate Models}

The multivariate models allow us to disentangle the effects of the explanatory variables, like need and living arrangements, which interest us. For example, we can determine whether men remain less likely than women to take up SSI once we take into account their other characteristics (for example

\footnotetext{
${ }^{28}$ The SIPP records linked to administrative data provide useful information on the character of SSI spells, not just participation. While only about five percent of the aged persons were receiving SSI at the time of the SIPP wave, more had been touched by the program, over eight percent of the observations in our sample in all. Of those persons in current SSI receipt, spell lengths were quite variable. While about a quarter were receiving SSI benefits for three years or fewer, most had received program benefits for a longer time. A very small fraction (less than one percent) had been receiving SSI since the program started in 1974.
} 
their higher earnings and Social Security benefits and their greater likelihood of being married than women in this age range). For both of our joint models of living arrangements and SSI participation, we present cross-sectional estimates. When reporting results from our models of living arrangements and SSI receipt and their cross, we present the multivariate probit and multinomial logistic regression coefficients and the corrected standard errors. We use asterisks to denote statistically significant effects.

\section{Joint Model of Living Arrangements and SSI: Bivariate Probit}

Table 4 reports the results when we use the bivariate probit approach to introducing simultaneity in living arrangements and SSI receipt. Interpretation of this model is more straightforward than with the multinomial logit model. The reference categories are simply not collecting SSI (for the program participation equation) and living alone (for the coresidence equation), rather than their cross.

The equation for SSI program participation shows the hypothesized pattern of declining participation probability with Social Security and pension income. (When interpreting the effects of the magnitudes of Social Security and pension income, one needs to take into account the presence of the indicator variables for these types of income. The probability of occupying this state thus only begins to increase after income has exceeded the level implied by the indicator variable coefficient.) The equation also shows an increased probability of participation with SSI and Social Security experience, and higher state supplements. Together, these coefficients suggest that participation in SSI is closely tied to need and incentives. Several demographic control variables also have significant effects on SSI participation. Eligible men are significantly less likely to participate in SSI than eligible women, and the probability of participation declines with age. Not surprisingly, prior SSI exposure correlates strongly with participation at any point in time.

To provide some sense of the magnitudes of these changes, we calculated the marginal effects of changes to key variables, assuming that all other variables take their mean values. ${ }^{29}$ The effect of being male, for example, amounts to a 12.8 percent reduction in SSI take-up probability at this point.

\footnotetext{
${ }^{29}$ For dichotomous variables, we compare the change in predicted probability from when the variable is equal to zero to when it is equal to one.
} 
Having been born abroad, in contrast, leads to a 13.8 percent increase in likelihood of participation. An increase in Social Security benefits of $\$ 100$ per month would reduce SSI take-up by 8.1 percent, but when we net out the Social Security participation effect, this reduction falls to 3.7 percent. A corresponding $\$ 100$ monthly increase in SSI benefits would increase take-up by 4.8 percent. Prior SSI exposure dwarfs all other effects in the equation, increasing the likelihood of participating in the program now by 83.7 percent.

For the coresidence equation, kin availability (measured by number of children) has positive, significant effects on the likelihood of sharing a residence, consistent with prior literature. Being an immigrant, living in the South, not having worked in many years, and being unmarried (specifically, being widowed or never married) also increase coresidence probabilities. These differences in likelihood of sharing living arrangements by nativity and region may suggest differential norms (see, for example, Wilmoth, 2001). Previous SSI experience is negatively correlated with coresidence.

Once more, computing marginal effects help us to better understand the relative impacts of the predictors. When all other variables are set at their means, each additional child increases coresidence likelihood by 3.6 percent. Being foreign born has a much larger effect, equaling about a 13.1 percent increase. Southern residence also has a substantial, positive effect, equaling 8.1 percent. Being widowed increases likelihood by 9.1 percent and being never married by 10.1 percent. Previous SSI experience reduces coresidence more modestly, by about a half percent.

We see that the correlation between the error terms of the two equations is negative and statistically significant, suggesting that we should consider these two processes jointly. Furthermore, the negative sign for this correlation indicates that any unmeasured factors that encourage participation in SSI tend to discourage living with others. This suggests, in turn, that receipt of SSI benefits tends to encourage independent living arrangements, and vice versa. ${ }^{30}$

\section{Joint Model of Living Arrangements and SSI: Multinomial Logit}

The results from the second joint model, the multinomial logit, are more challenging to interpret than the results from the bivariate probit model of living arrangements and SSI (Table 5). As the model 
reference group, we choose the most prevalent cross-classification: Those who are not coresiding but who are collecting SSI. The coefficients in each of the three columns thus represent the effects of a one-unit change in the covariates on the log-odds of falling into the respective group relative to the reference group.

Column 3 of Table 5, for example, presents effects for the comparison between being an SSI recipient who does not share a residence and being a person who neither collects SSI nor coresides. Consistent with findings from the prior model of SSI and living arrangements, we find that higher Social Security benefits make SSI-eligible persons more likely to occupy the neither collect SSI nor coreside category relative to the reference group of not coresiding and collecting SSI. Being older, being in fair or poor health, being male, and having had previous experience with SSI all make one less likely to occupy this category relative to the base. All else equal, married people are more likely than those who never married, are widowed, or divorced to be in this status (relative to the reference).

The variable measuring the generosity of state supplemental SSI benefits is negative and highly significant in this component of the model. In order to illustrate the quantitative significance of this finding, we have computed the predicted probabilities of the four categories of living arrangements and SSI receipt, for a range of values of the SSI supplement variable. The range considered is zero through $\$ 575 /$ month (slightly higher than the maximum of $\$ 567$ observed in our data). The calculations are for individuals with otherwise average propensities to fall into the four categories of the dependent variable.

The predicted probabilities are plotted in Figure 1. It is evident that as states provide more generous SSI supplements, the probability of being an SSI beneficiary—whether simultaneously living independently, or coresiding — rises, and the increase is larger for those jointly receiving benefits and living independently. The probabilities of not receiving SSI benefits necessarily fall as supplements grow in generosity. If the probabilities of living independently with or without SSI benefit receipt are added, producing an unconditional probability of independent living (not shown), the curve is virtually flat. Finally, if the conditional probability of living independently given SSI receipt is computed (also not shown), the resulting curve is once again virtually flat. Thus, our model indicates that state policy towards SSI benefits has pronounced effects on beneficiary status, but not on living arrangements.

\footnotetext{
${ }^{30}$ While this negative and significant effect was fairly robust, the signs and significance levels of other key coefficients changed across alternative specifications. This suggests that we should interpret results from these
} 
Returning to the model coefficients, Column 1 reveals that being foreign born, from the South, or having more children, and thus opportunities for coresidence, make one more likely to be a member of the share-and-collect group than of the reference group. Column 2 shows that far more variables are significantly related to being in the group that shares a home and does not collect SSI (again relative to the base category of being independent and collecting benefits). These include being male, never married or widowed, having higher Social Security income, and not having worked in a longer time. The number of children one has had also has a positive effect. Asset variance, homeownership, SSI experience, and having other than a high school education are also significantly, negatively related to being a coresident who does not collect SSI relative to a person who lives alone and does collect.

Table 6 presents the relative risk ratios for a one-unit change in the explanatory variables in the multinomial logit model. For example, the relative risk ratio of 1.17 for number of children in column 1 suggests that having a child increases the probability of choosing collecting SSI and sharing living arrangements over collecting SSI and living independently by 17 percent. Ratios of less than one indicate that the coefficient on that variable was negative and therefore that a one unit change in the variable decreases the probability of occupying the state. The ratio of 0.49 on being foreign born (in column 3) suggests that immigrants face a lower probability of not collecting SSI and living independently (relative to collecting SSI and living independently).

\section{Conclusions}

Our analyses support findings from many previous studies of SSI and living arrangements. We find aged SSI take-up rates of about sixty percent, with program take-up increasing when need and state supplements increase. We also find that the strong connection between living arrangements and kin availability found in the literature on living arrangements does apply to the very select population of SSI eligibles. When we examine the intersection of these processes, we find modest evidence that living arrangements and SSI receipt choices are connected for these low-income individuals and couples. SSI participation appears to depress levels of coresidence, and coresidence appears to mute SSI participation.

analyses conservatively. 
Our findings have implications for SSI policy. Over the past decade, the SSI population has become increasingly select and needy as asset screens, exclusions, and many state supplements have not kept up with inflation. Given that so few SSI recipients receive reductions for living in the home of another, even relative to the population of coresiders, one might question the target and administrative efficiency of maintaining these regulations (Social Security Administration 2000). Our findings on state supplements suggest that low-income aged persons will respond to initiatives that restore program benefits and eligibility to the real levels that prevailed earlier in SSI's history. Perhaps most importantly, policymakers should recognize the complex linkages that exist between income and medical support programs and family demographic behaviors. 


\section{References}

Börsch-Supan, Axel H. 1990. “A Dynamic Analysis of Household Dissolution and Living Arrangement Transitions by Elderly Americans." In David A. Wise, Ed. Issues in the Economics of Aging. Chicago: University of Chicago Press.

Burke, Vincent J. and Vee Burke. 1974. Nixon's Good Deed: Welfare Reform. New York: Columbia University Press.

Committee on Ways and Means, United States House of Representatives. 2003. Overview of Entitlement Programs: 2003 Green Book Background Material and Data on Programs Within the Jurisdiction of the Committee on Ways and Means. Washington, DC: U.S. Government Printing Office.

Davies, Paul S., Minh Huynh, Chad Newcomb, Paul O'Leary, Kalman Rupp, and Jim Sears. 2002. "Modeling SSI Financial Eligibility and Simulating the Effect of Policy Options." Social Security Bulletin 64(2): 16-45.

Engelhardt, Gary V., Jonathan Gruber, and Cynthia D. Perry. 2002. "Social Security and Elderly Living Arrangements." Cambridge, MA: National Bureau of Economic Research [Working Paper 8911].

Giannarelli, Linda and Laura Wheaton. 2000. "Under-Reporting of Means-Tested Transfer Programs in the March CPS." Brownbag presentation at the Urban Institute, February 29.

Huynh, Minh, Kalman Rupp, and James Sears. 2002. "The Assessment of Survey of Income and Program Participation (SIPP) Benefit Data using Longitudinal Administrative Records.” SIPP Working Paper No. 238. Washington, DC: U.S. Census Bureau.

Kochhar, Satya and Charles G. Scott. 1997. “Living Arrangements of SSI Recipients.” Social Security Bulletin 60(1): 18-28.

Kotlikoff, Laurence J. and John N. Morris. 1990. "Why Don't the Elderly Live with their Children? A New Look." In David A. Wise, Ed. Issues in the Economics of Aging. Chicago: University of Chicago Press.

Macunovich, Diane J., Richard A. Easterlin, Christine M. Schaeffer, and Eileen M. Crimmins. 1995. "Echoes of the Baby Boom and Bust: Recent and Prospective Changes in Living Alone Among Elderly Widows in the United States." Demography 32(1): 17-28.

McGarry, Kathleen. 1996. "Factors Determining Participation of the Elderly in Supplemental Security Income." Journal of Human Resources 31(2): 331-358. 
. 2000. "Guaranteed Income: SSI and the Well-Being of the Elderly Poor."

Cambridge, MA: National Bureau of Economic Research [Working Paper number 7574].

McGarry, Kathleen and Robert F. Schoeni. 2000. "Social Security, Economic Growth, and the Rise in Elderly Widows' Independence in the Twentieth Century." Demography 37(2): 221-236.

Parrott, Thomas M., Lenna D.Kennedy, and Charles G. Scott. 1998. "Noncitizens and the Supplemental Security Income Program.” Social Security Bulletin 61(4): 3-31

Rendall, Michael S. and Alden Speare, Jr. 1995. "Elderly Poverty Alleviation through Living with Family." Journal of Population Economics 8: 383-405.

Select Committee on Aging, United States House of Representatives. 1987. The Forgotten Safety Net: The Supplemental Security Income (SSI) Program. Hearing Before the Subcommittee on Retirement Income and Employment. Washington, DC: U.S. Government Printing Office.

Scott, Charles G. and Elsa Ponce. 1994. “Aliens Who Receive SSI Payments.” [Unpublished manuscript.]

Social Security Administration. 2000. Simplifying the Supplemental Security Income Program: Challenges and Opportunities. Baltimore, MD: Author. (Obtained via website, URL as follows: http://www.ssa.gov/policy/programs/SSI/simplification/simplification.pdf, accessed March 1, 2003.)

Social Security Administration. 2002a. Annual Statistical Supplement to the Social Security Bulletin. Washington, DC: Author.

Social Security Administration. 2002b. SSI Annual Statistical Report. Washington, DC: Author.

Soldo, Beth J., Douglas A. Wolf, and Vicki A. Freedman. 1995. "Co-Residence with an Older Mother: The Adult Child's Perspective." Syracuse, NY: Maxwell Aging Studies Program Paper number 3.

Stata Corporation. 2001. Stata User's Guide Release 7. College Station, TX: Stata Press.

Tissue, Thomas and John L. McCoy. 1981. "Income and Living Arrangements Among Poor Aged Singles." Social Security Bulletin 44(4): 3-13.

Urban Systems Research and Engineering, Inc. 1981. SSI Aged: A Pilot Study of Eligibility and Participation in the Supplemental Security Income Program. Cambridge, MA: Author. 
Warlick, Jennifer L. 1982. "Participation of the Aged in SSI." Journal of Human Resources 17(2): 236-260.

Wilmoth, Janet M. 2001. "Living Arrangements Among Older Immigrants in the United States." The Gerontologist 41(2): 228-238.

Wolf, Douglas A. 1994. "The Elderly and Their Kin: Patterns of Availability and Access." In Linda G. Martin and Samuel H. Preston, eds. The Demography of Aging. Washington, DC: National Academy Press.

Wolf, Douglas A. and Beth J. Soldo. 1988. "Household Composition Choices of Older Unmarried Women.” Demography 25: 387-403. 
Figure 1: Predicted Probabilities from MNL Model, by Level of State Supplement

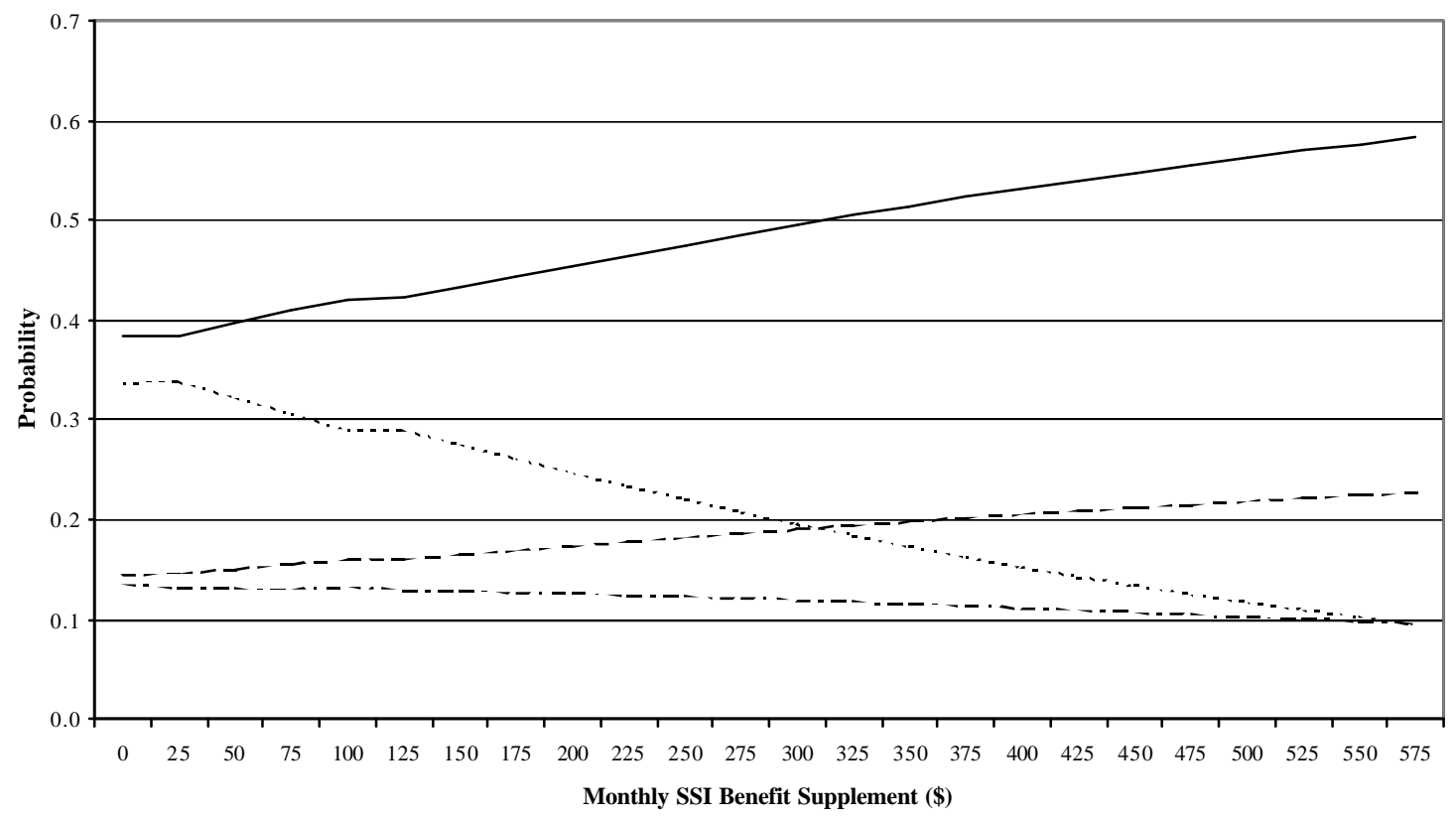

$\longrightarrow$ SSI, independent --- SSI, coreside $-\cdots$ no SSI, coreside $\cdots \cdots$ no SSI, independent 
Table 1. Living Arrangements of the SIPP Population Ages 65 and Older

\begin{tabular}{|c|c|c|c|c|}
\hline & $\begin{array}{c}\text { Percent of } \\
\text { Entire } \\
\text { Sample } \\
\end{array}$ & $\begin{array}{c}\text { Percent of } \\
\text { Married } \\
\text { People } \\
\end{array}$ & $\begin{array}{c}\text { Percent of } \\
\text { Unmarried } \\
\text { Men } \\
\end{array}$ & $\begin{array}{c}\text { Percent of } \\
\text { Unmarried } \\
\text { Women } \\
\end{array}$ \\
\hline & $(1)$ & (2) & (3) & (4) \\
\hline \multicolumn{5}{|l|}{ Type of Living Arrangement } \\
\hline Alone, or with spouse only & 82.46 & 87.64 & 79.93 & 74.15 \\
\hline $\begin{array}{l}\text { With relatives (other than or in addition to a spouse) } \\
\text { who are at least } 30 \text { years of age }\end{array}$ & 17.54 & 12.36 & 20.07 & 25.85 \\
\hline Live with child age $>=30$ & 12.38 & 10.36 & 9.98 & 16.6 \\
\hline Live with other relatives & 3.47 & 1.91 & 4.62 & 5.85 \\
\hline Live with sibling & 1.90 & 0.27 & 3.85 & 5.00 \\
\hline Live with parent & 0.68 & 0.40 & 1.46 & 0.94 \\
\hline Sample Size (Unweighted) & 222,040 & 126,577 & 21,062 & 72,401 \\
\hline
\end{tabular}

Source: Authors' tabulations from the Survey of Income and Program Participation, 1990-1993.

Notes: The unit of analysis is a person-wave. Observations are weighted, and restricted to persons with valid data from the wealth topical module. The child designation includes foster and stepchildren, as well as grandchildren. 
Table 2. SSI Eligibility and Participation for Persons 65 and Older from SIPP, by Sex

\begin{tabular}{|c|c|c|c|c|c|c|}
\hline & \multirow{2}{*}{\multicolumn{2}{|c|}{$\begin{array}{l}\text { Percent Eligible for } \\
\text { SSI } \\
\text { (1) } \\
\end{array}$}} & \multirow{2}{*}{\multicolumn{2}{|c|}{$\begin{array}{l}\text { Percent of Eligibles } \\
\text { Participating in SSI } \\
\text { (2) } \\
\end{array}$}} & \multirow{2}{*}{\multicolumn{2}{|c|}{$\begin{array}{c}\text { Unweighted } \mathrm{N} \text { for } \\
\text { Eligibles (person } \\
\text { waves) } \\
(3) \\
\end{array}$}} \\
\hline & & & & & & \\
\hline & Women & Men & Women & Men & Women & Men \\
\hline & \multicolumn{2}{|c|}{10.74} & \multicolumn{2}{|c|}{58.78} & \multicolumn{2}{|c|}{19,063} \\
\hline All & 12.75 & 6.23 & 60.41 & 50.57 & 14,244 & 4,819 \\
\hline Live independently & 10.91 & 5.40 & 61.51 & 40.95 & 9,139 & 3,388 \\
\hline Other (shared) living situation & 20.96 & 12.29 & 58.72 & 53.78 & 4,711 & 1,299 \\
\hline Married & 4.01 & 4.06 & 59.96 & 54.80 & 1,727 & 2,337 \\
\hline Never married & 24.08 & 20.82 & 52.40 & 46.97 & 1,310 & 675 \\
\hline Widowed & 16.48 & 8.61 & 58.50 & 49.17 & 8,745 & 950 \\
\hline Divorced or separated & 28.16 & 17.38 & 78.50 & 46.49 & 2,168 & 756 \\
\hline Age 65-69 & 10.08 & 5.95 & 63.17 & 54.75 & 3,939 & 1,777 \\
\hline Age $70-74$ & 13.25 & 7.36 & 62.86 & 55.94 & 1,939 & 728 \\
\hline Age $75-79$ & 12.83 & 5.29 & 60.80 & 39.81 & 2,836 & 835 \\
\hline Age 80 plus & 16.2 & 6.99 & 55.66 & 44.84 & 4,189 & 961 \\
\hline At least some college & 5.35 & 2.27 & 45.84 & 62.42 & 1,134 & 525 \\
\hline High school graduate & 6.52 & 3.57 & 44.58 & 39.61 & 2,581 & 818 \\
\hline$<$ high school graduate & 22.55 & 11.06 & 67.17 & 51.33 & 10,458 & 3,451 \\
\hline White & 9.81 & 4.53 & 54.59 & 51.94 & 9,521 & 3,201 \\
\hline Black & 38.38 & 20.55 & 75.31 & 42.23 & 3,903 & 1,139 \\
\hline Asian & 42.33 & 33.20 & 72.48 & 72.00 & 726 & 437 \\
\hline Native American & 25.14 & 19.09 & 82.63 & na & 94 & 42 \\
\hline Hispanic (any race) & 47.36 & 26.09 & 68.21 & 77.07 & 1,240 & 482 \\
\hline Foreign born & 29.94 & 24.51 & 66.99 & 59.55 & 2,767 & 1,275 \\
\hline Social Security recipients & 10.49 & 4.95 & 58.92 & 49.29 & 10,940 & 3,671 \\
\hline $\begin{array}{l}\text { Bottom half of income } \\
\text { distribution for eligibles }\end{array}$ & - & - & 70.30 & 59.59 & 8,603 & 2,866 \\
\hline $\begin{array}{l}\text { Top half of income distribution } \\
\text { for eligibles }\end{array}$ & 一 & - & 47.11 & 37.70 & 1,953 & 5,641 \\
\hline 1990 SIPP & 12.73 & 6.27 & 54.95 & 54.59 & 4,321 & 1,426 \\
\hline 1991 SIPP & 14.24 & 8.20 & 57.79 & 50.06 & 2,538 & 958 \\
\hline 1992 SIPP & 12.75 & 6.23 & 60.90 & 50.93 & 4,052 & 1,350 \\
\hline 1993 SIPP & 12.42 & 6.26 & 59.91 & 54.10 & 3,333 & 1,085 \\
\hline Car owner & 4.94 & 2.67 & 64.28 & 51.04 & 3,621 & 2,054 \\
\hline Homeowner & 5.99 & 2.53 & 57.93 & 43.05 & 4,491 & 1,541 \\
\hline Health excellent to good & 7.87 & 3.49 & 52.86 & 45.94 & 5,358 & 1,811 \\
\hline Health fair or poor & 20.25 & 10.85 & 66.28 & 54.47 & 8,512 & 2,882 \\
\hline
\end{tabular}

Source: Authors' tabulations from the Survey of Income and Program Participation, 1990-1993, matched to the SER and SSR.

Notes: The unit of analysis is a person wave. Eligibility and participation estimates are weighted, and restricted to persons present for the wealth topical module. "na" indicates cell size too small to be reliable. 
Table 3. Joint Distribution of SSI Participation and Living Arrangements Among SSI Eligible Persons Ages 65 and Older in the SIPP, by Sex and Marital Status

\begin{tabular}{|c|c|c|c|c|c|c|c|c|c|}
\hline & \multicolumn{2}{|c|}{ Married } & \multicolumn{2}{|c|}{ Divorced } & \multicolumn{2}{|c|}{ Widowed } & \multicolumn{2}{|c|}{ Never Married } & \multirow[b]{2}{*}{ All } \\
\hline & Women & Men & Women & Men & Women & Men & Women & Men & \\
\hline $\begin{array}{l}\text { Share and } \\
\text { collect SSI }\end{array}$ & 7.95 & 12.7 & 13.02 & 6.7 & 20.48 & 9.44 & 22.74 & 6.8 & 15.96 \\
\hline $\begin{array}{l}\text { Share but do } \\
\text { not collect SSI }\end{array}$ & 13.58 & 16.81 & 4.30 & 7.18 & 14.77 & 21.91 & 8.04 & 10.18 & 13.13 \\
\hline $\begin{array}{l}\text { Do not share } \\
\text { but collect SSI }\end{array}$ & 51.56 & 42.22 & 64.83 & 38.73 & 37.86 & 40.18 & 29.94 & 38.66 & 42.09 \\
\hline $\begin{array}{l}\text { Neither share } \\
\text { nor collect SSI }\end{array}$ & 26.91 & 28.27 & 17.85 & 47.39 & 26.88 & 28.47 & 39.29 & 44.36 & 28.81 \\
\hline
\end{tabular}

Table entries indicate percent of SSI eligible persons with the given SSI-living arrangements status. Source: Authors' tabulations from the Survey of Income and Program Participation, 1990-1993, matched to the SER and SSR.

Notes: Estimates are weighted, and restricted to persons present for the wealth topical module. Unit of analysis is a person wave. Percentages may not add to 100 percent because of rounding. 
Table 4. Bivariate Probit Model of Joint SSI-Living Arrangements States among the SSI Eligible Ages 65 and Older

\begin{tabular}{|c|c|c|c|c|}
\hline \multirow[t]{2}{*}{ Variables } & \multicolumn{2}{|c|}{ Collect SSI } & \multicolumn{2}{|c|}{ Share Living Arrangements } \\
\hline & Coefficient & $S E$ & Coefficient & $S E$ \\
\hline Intercept & -0.1489 & 0.5053 & $-0.8470 * *$ & 0.4222 \\
\hline \multicolumn{5}{|l|}{ Demographics } \\
\hline Male & $-0.3231 * * *$ & 0.0880 & -0.0582 & 0.0697 \\
\hline Never Married & -0.1331 & 0.1509 & $0.2743 *$ & 0.1409 \\
\hline Divorced/Separated & -0.0676 & 0.1309 & 0.0116 & 0.1228 \\
\hline Widowed & -0.0192 & 0.1086 & $0.2475 * *$ & 0.1038 \\
\hline Age & $-0.0211 * * *$ & 0.0067 & -0.0013 & 0.0056 \\
\hline Spouse age $>65$ & 0.2592 & 0.1945 & 0.0876 & 0.1497 \\
\hline Black & 0.1102 & 0.0876 & 0.0505 & 0.0773 \\
\hline Native American & -0.1275 & 0.4431 & -0.3559 & 0.4142 \\
\hline Hispanic & 0.0150 & 0.1401 & 0.1677 & 0.1184 \\
\hline Asian & 0.2254 & 0.1910 & 0.0630 & 0.1774 \\
\hline Foreign born & $0.3522 * * *$ & 0.1171 & $0.3620 * * *$ & 0.1040 \\
\hline Number of children & 0.0106 & 0.0176 & $0.1027 * * *$ & 0.0154 \\
\hline Health is fair or poor & 0.1080 & 0.0709 & -0.0301 & 0.0615 \\
\hline From South & 0.1212 & 0.0907 & $0.2288 * * *$ & 0.0827 \\
\hline \multicolumn{5}{|l|}{ Experience and Attainments } \\
\hline Years since worked & 0.0005 & 0.0038 & $0.0105 * * *$ & 0.0036 \\
\hline Total labor force experience & 0.0001 & 0.0053 & 0.0017 & 0.0047 \\
\hline Education $>$ high school & 0.0318 & 0.1560 & $-0.3639 * * *$ & 0.1261 \\
\hline Education $<$ high school & 0.1264 & 0.1034 & $-0.2087 * * *$ & 0.0839 \\
\hline \multicolumn{5}{|l|}{ Program participation } \\
\hline Social Security income & $-3.9305 * * *$ & 0.7075 & -0.1737 & 0.6567 \\
\hline Social Security history & $0.5118 * * *$ & 0.1495 & -0.0924 & 0.1490 \\
\hline Any SSI experience & $2.8315 * * *$ & 0.0733 & $-0.1652 * *$ & 0.0657 \\
\hline Pension income & $-4.5446 * *$ & 2.1452 & -0.4635 & 1.9027 \\
\hline Pension coverage & 0.0420 & 0.2129 & 0.2521 & 0.2084 \\
\hline Asset income & -1.0155 & 1.2352 & 0.2263 & 1.8755 \\
\hline Asset variance & 0.5967 & 0.7527 & $-3.0461 *$ & 1.7739 \\
\hline \multicolumn{5}{|l|}{ Wealth } \\
\hline Own a car & -0.1348 & 0.0878 & -0.0082 & 0.0803 \\
\hline Own a home & -0.0683 & 0.0833 & $-0.4490 * * *$ & 0.0757 \\
\hline \multicolumn{5}{|l|}{ Policy } \\
\hline State supplement/average wage & $2.3153 * * *$ & 0.7591 & 0.5663 & 0.7536 \\
\hline \multicolumn{5}{|l|}{ Rho (Correlation of error terms) } \\
\hline Rho & & $-0.1541^{* * *}$ & 0.0469 & \\
\hline$N$ (person waves) & & 13,3 & & \\
\hline Average number of obs/person & & 6.9 & & \\
\hline Log pseudo-likelihood & & $-11,28$ & 3.03 & \\
\hline
\end{tabular}

* indicates $\mathrm{p}<0.10, * *$ indicates $\mathrm{p}<0.05, * * *$ indicates $\mathrm{p}<0.01$

Source: 1990-93 Survey of Income and Program Participation matched to SER and SSR.

Notes: Income variables (Social Security, pension, and asset) are per capita for couples, adjusting for economies of scale by dividing by the square root of two. Coverage and experience variables (pension coverage and Social Security experience) are for either member of a couple.

Standard errors correct for multiple observations of the same individual. 
Table 5. Multinomial Logit Model of Joint SSI-Living Arrangements States among the SSI Eligible Ages 65 and Older

\begin{tabular}{|c|c|c|c|c|c|c|}
\hline \multirow[t]{2}{*}{ Variables } & \multicolumn{2}{|c|}{$\begin{array}{l}\text { Collect and share vs. collect } \\
\text { and independent } \\
(1)\end{array}$} & \multicolumn{2}{|c|}{$\begin{array}{l}\text { Not collect and share vs. } \\
\text { collect and independent } \\
\text { (2) }\end{array}$} & \multicolumn{2}{|c|}{$\begin{array}{l}\text { Not collect and independent } \\
\text { vs. collect and independent } \\
\text { (3) }\end{array}$} \\
\hline & Coefficient & $S E$ & Coefficient & $S E$ & Coefficient & $S E$ \\
\hline Intercept & -1.3641 & 0.9282 & -1.2716 & 1.2454 & 0.3601 & 1.1236 \\
\hline \multicolumn{7}{|l|}{ Demographics } \\
\hline Male & -0.1094 & 0.1631 & $0.4552 * *$ & 0.2115 & $0.6571 * * *$ & 0.1880 \\
\hline Never Married & 0.4811 & 0.3095 & $0.6830 *$ & 0.4107 & 0.1891 & 0.3344 \\
\hline Divorced/Separated & -0.1564 & 0.2753 & 0.2819 & 0.3305 & 0.0797 & 0.2963 \\
\hline Widowed & 0.2194 & 0.2267 & $0.5206 *$ & 0.2787 & -0.1644 & 0.2390 \\
\hline Age & 0.0042 & 0.0121 & $0.0332 * *$ & 0.0167 & $0.0438 * * *$ & 0.0149 \\
\hline Spouse age $>65$ & 0.1858 & 0.1333 & $-0.4012 * *$ & 0.2019 & $-0.5462 * * *$ & 0.1771 \\
\hline Black & -0.0130 & 0.1686 & -0.0672 & 0.2216 & -0.2662 & 0.1959 \\
\hline Native American & $-2.2052 * *$ & 1.1008 & -0.1504 & 0.9345 & -0.2523 & 1.0298 \\
\hline Hispanic & 0.2061 & 0.2452 & 0.2785 & 0.3391 & -0.1521 & 0.3327 \\
\hline Asian & -0.0665 & 0.3416 & -0.2901 & 0.4614 & -0.5726 & 0.4359 \\
\hline Foreign born & $0.5880 * * *$ & 0.2251 & -0.1245 & 0.2949 & $-0.7201 * * *$ & 0.2754 \\
\hline Number of children & $0.1586 * * *$ & 0.0335 & $0.1391 * * *$ & 0.0446 & -0.0562 & 0.0394 \\
\hline Health is fair or poor & -0.1981 & 0.1353 & -0.1517 & 0.1746 & $-0.3340 * *$ & 0.1565 \\
\hline From South & $0.4266 * *$ & 0.1814 & 0.1675 & 0.2248 & -0.2331 & 0.2048 \\
\hline \multicolumn{7}{|l|}{ Experience and Attainments } \\
\hline Years since worked & 0.0094 & 0.0078 & $0.0223 * *$ & 0.0107 & -0.0068 & 0.0082 \\
\hline $\begin{array}{l}\text { Total labor force } \\
\text { experience }\end{array}$ & -0.0078 & 0.0115 & 0.0095 & 0.0145 & -0.0065 & 0.0110 \\
\hline Education > high school & -0.1484 & 0.2895 & $-0.8275 * *$ & 0.4172 & 0.2728 & 0.3422 \\
\hline Education $<$ high school & -0.2159 & 0.2003 & $-0.5910 * *$ & 0.2354 & -0.1356 & 0.2248 \\
\hline \multicolumn{7}{|l|}{ Program participation } \\
\hline Social Security income & -0.5852 & 1.4930 & $6.6629 * * *$ & 1.7538 & $8.3864 * * *$ & 1.5386 \\
\hline Social Security history & -0.1569 & 0.3265 & $-0.9583 * *$ & 0.4036 & $-1.1726 * * *$ & 0.3318 \\
\hline Any SSI experience & -0.2865 & 0.2179 & $-5.0303 * * *$ & 0.2201 & $-5.1980 * * *$ & 0.1815 \\
\hline Pension income & -5.9537 & 6.0644 & 7.1857 & 5.4135 & 5.8744 & 4.3622 \\
\hline Pension coverage & 0.9064 & 0.5922 & 0.2820 & 0.5338 & 0.2170 & 0.5086 \\
\hline Asset income & 3.4548 & 5.1339 & 0.9673 & 4.9457 & 2.1589 & 2.6230 \\
\hline Asset variance & -5.4608 & 10.1534 & $-9.8973 * *$ & 5.0733 & -1.0730 & 1.6055 \\
\hline \multicolumn{7}{|l|}{ Wealth } \\
\hline Own a car & -0.0256 & 0.1833 & 0.2294 & 0.2231 & 0.2368 & 0.1895 \\
\hline Own a home & $-0.9094 * * *$ & 0.1790 & $-0.5083 * *$ & 0.2143 & 0.1493 & 0.1820 \\
\hline \multicolumn{7}{|l|}{ Policy } \\
\hline $\begin{array}{l}\text { State Supplement/ average } \\
\text { wage }\end{array}$ & 0.1070 & 1.6170 & -2.6186 & 1.9821 & $-6.0334 * * *$ & 1.6640 \\
\hline $\mathrm{N}$ (person waves) & \multicolumn{6}{|c|}{13,319} \\
\hline Average number of & \multicolumn{6}{|c|}{6.9} \\
\hline Log-pseudo-likelihood & \multicolumn{6}{|c|}{$-11,199.3150$} \\
\hline
\end{tabular}

* indicates $\mathrm{p}<0.10, * *$ indicates $\mathrm{p}<0.05, * * *$ indicates $\mathrm{p}<0.01$

Source: 1990-93 Survey of Income and Program Participation matched to SER and SSR.

Notes: Income variables (Social Security, pension, and asset) are per capita for couples, adjusting for economies of scale by dividing by the square root of two. Coverage and experience variables (pension coverage and Social Security experience) are for either member of a couple. Standard errors correct for multiple observations of the same individual. 
Table 6. Relative Risk Rations from Multinomial Logit Model of Joint SSI-Living Arrangements States among the SSI Eligible Ages 65 and Older

\begin{tabular}{|c|c|c|c|c|c|c|}
\hline \multirow[t]{2}{*}{ Variables } & \multicolumn{2}{|c|}{$\begin{array}{l}\text { Collect and share vs. collect } \\
\text { and independent } \\
(1)\end{array}$} & \multicolumn{2}{|c|}{$\begin{array}{l}\text { Not collect and share vs. } \\
\text { collect and independent } \\
\text { (2) }\end{array}$} & \multicolumn{2}{|c|}{$\begin{array}{l}\text { Not collect and independent } \\
\text { vs. collect and independent } \\
\text { (3) }\end{array}$} \\
\hline & $R R R$ & $S E$ & $R R R$ & $S E$ & $R R R$ & $\overline{S E}$ \\
\hline \multicolumn{7}{|l|}{ Demographics } \\
\hline Male & 0.8964 & 0.1462 & $1.5766 * *$ & 0.3335 & $1.9292 * * *$ & 0.3627 \\
\hline Never Married & 1.6179 & 0.5007 & $1.9798 *$ & 0.8131 & 1.2082 & 0.4040 \\
\hline Divorced/Separated & 0.8552 & 0.2355 & 1.3256 & 0.4382 & 1.0830 & 0.3209 \\
\hline Widowed & 1.2454 & 0.2823 & $1.6830 *$ & 0.4690 & 0.8484 & 0.2028 \\
\hline Age & 1.0043 & 0.0122 & $1.0338 * *$ & 0.0172 & $1.0448 * * *$ & 0.0156 \\
\hline Spouse age $>65$ & 1.2042 & 0.3977 & 0.6695 & 0.3311 & 0.5792 & 0.2402 \\
\hline Black & 0.9871 & 0.1664 & 0.9350 & 0.2072 & 0.7663 & 0.1501 \\
\hline Native American & $0.1102 * *$ & 0.1213 & 0.8604 & 0.8040 & 0.7770 & 0.8001 \\
\hline Hispanic & 1.2288 & 0.3013 & 1.3211 & 0.4479 & 0.8589 & 0.2858 \\
\hline Asian & 0.9357 & 0.3197 & 0.7482 & 0.3452 & 0.5640 & 0.2459 \\
\hline Foreign born & $1.8003 * * *$ & 0.4052 & 0.8829 & 0.2603 & $0.4867 * * *$ & 0.1341 \\
\hline Number of children & $1.1719 * * *$ & 0.0393 & $1.1493 * * *$ & 0.0512 & 0.9454 & 0.0372 \\
\hline Health is fair or poor & 0.8203 & 0.1110 & 0.8592 & 0.1500 & $0.7160 * *$ & 0.1121 \\
\hline From South & $1.5320 * * *$ & 0.2779 & 1.1823 & 0.2657 & 0.7921 & 0.1622 \\
\hline \multicolumn{7}{|l|}{ Experience and Attainments } \\
\hline Years since worked & 1.0094 & 0.0078 & $1.0226 * *$ & 0.0110 & 0.9933 & 0.0081 \\
\hline $\begin{array}{l}\text { Total labor force } \\
\text { experience }\end{array}$ & 0.9923 & 0.0114 & 1.0095 & 0.0146 & 0.9935 & 0.0110 \\
\hline Education $>$ high school & 0.8621 & 0.2496 & $0.4371 * *$ & 0.1824 & 1.3137 & 0.4496 \\
\hline Education $<$ high school & 0.8058 & 0.1614 & $0.5538 * *$ & 0.1304 & 0.8732 & 0.1963 \\
\hline \multicolumn{7}{|l|}{ Program participation } \\
\hline Social Security income & 0.5570 & 0.8316 & $782.8325 * * *$ & 1372.9490 & $4386.9390 * * *$ & 6749.6950 \\
\hline Social Security history & 0.8548 & 0.2791 & $0.3835 * *$ & 0.1548 & $0.3096 * * *$ & 0.1027 \\
\hline Any SSI experience & 0.7509 & 0.1636 & $0.0065 * * *$ & 0.0014 & $0.0055 * * *$ & 0.0010 \\
\hline Pension income & 0.0026 & 0.0157 & 1320.3470 & 7147.6930 & 355.8127 & 1552.1260 \\
\hline Pension coverage & 2.4754 & 1.4658 & 1.3258 & 0.7078 & 1.2423 & 0.6318 \\
\hline Asset income & 31.6519 & 162.4989 & 2.6308 & 13.0110 & 8.6620 & 22.7200 \\
\hline Asset variance & 0.0043 & 0.0432 & $0.0001 *$ & 0.0003 & 0.3420 & 0.5490 \\
\hline \multicolumn{7}{|l|}{ Wealth } \\
\hline Own a car & 0.9747 & 0.1786 & 1.2579 & 0.2807 & 1.2672 & 0.2401 \\
\hline Own a home & $0.4028 * * *$ & 0.0721 & $0.6015 * *$ & 0.1289 & 1.1610 & 0.2114 \\
\hline \multicolumn{7}{|l|}{ Policy } \\
\hline $\begin{array}{l}\text { State Supplement/ average } \\
\text { wage }\end{array}$ & 1.1130 & 1.7997 & 0.0729 & 0.1445 & $0.0024 * * *$ & 0.0040 \\
\hline $\mathrm{N}$ (person waves) & \multicolumn{6}{|c|}{13,319} \\
\hline $\begin{array}{l}\text { Average number of } \\
\text { obs/person }\end{array}$ & \multicolumn{6}{|c|}{6.9} \\
\hline
\end{tabular}

$*$ indicates $\mathrm{p}<0.10, * *$ indicates $\mathrm{p}<0.05, * * *$ indicates $\mathrm{p}<0.01$

Source: 1990-93 Survey of Income and Program Participation matched to SER and SSR.

Notes: Income variables (Social Security, pension, and asset) are per capita for couples, adjusting for economies of scale by dividing by the square root of two. Coverage and experience variables (pension coverage and Social Security experience) are for either member of a couple. Standard errors correct for multiple observations of the same individual. 


\section{RECENT WORKING PAPERS FROM THE \\ Center For Retirement Research at Boston College}

Simulating the Distributional Consequences of Personal Accounts: Sensitivity to Annuitization Options

Cori E. Uccello, Melissa M. Favreault, Karen E. Smith, and Lawrence H. Thompson, October 2003

Aggregate Implications of Defined Benefit and Defined Contribution Systems

Francisco Gomes and Alexander Michaelides, September 2003

Can Unexpected Retirement Explain the Retirement-Consumption Puzzle?

Evidence for Subjective Retirement Explanations

Melvin Stephens Jr. and Steven J. Haider, August 2003

Employment, Social Security and Future Retirement Outcomes for Single Mothers Richard W. Johnson, Melissa M. Favreault, and Joshua H. Goldwyn, July 2003

The Outlook for Pension Contributions and Profits in the U.S.

Alicia H. Munnell and Mauricio Soto, June 2003

Social Security Reform and the Exchange of Bequests for Elder Care

Meta Brown, June 2003

Annuities and Individual Welfare

Thomas Davidoff, Jeffrey Brown, and Peter Diamond, May 2003

Becoming Oldest-Old: Evidence for Historical U.S. Data

Dora Costa and Joanna Lahey, May 2003

The Evolution of Social Security Disabled Widow(er)s' Benefits

Eric R. Kingson, Margaret Morse, and Gary Calhoun, May 2003

Health Shocks and Couples' Labor Supply Decisions

Courtney Coile, May 2003

Whose Money is It Anyhow?: Governance and Social Investment in Collective Investment Funds

R. Kent Weaver, May 2003

The Politics of Public Pension Reform

R. Kent Weaver, May 2003

All working papers are available on the Center for Retirement Research website (http://www.bc.edu/crr) and can be requested by e-mail (crr@bc.edu) or phone (617-552-1762). 